\title{
Nitrogen Use Efficiency and Yield of Maize Varieties as affected by Nitrogen rate in Mid Altitude Areas of Western Ethiopia Tolera Abera $^{1}$, Dagne Wegary ${ }^{2}$ and Tolessa Debele ${ }^{3}$
}

\begin{abstract}
${ }^{1}$ Natural Resources Management Research Process, Ambo Agricultural Research Center, Ethiopian Institute of Agricultural Research, P.O. Box 382, Ambo, West Showa, Oromia, Ethiopia

${ }^{2}$ International Maize and Wheat Improvement Centre (CIMMYT), Global Conservation Agriculture Program, P O. Box 5689. Addis Ababa, Ethiopia

${ }^{3}$ Wheat Project coordinator Support to Agricultural Research for Development of Strategic Crops in Africa (SARD-SC), ICARDA c/o ILRI P.O. Box 5689 Addis Ababa, Ethiopia
\end{abstract}

Corresponding email: thawwii@yahoo.com, thawwii2014@gmail.com,tolera.abera@eiar.gov.et

Abstract: Maize (Zea mays L.) is the most widely grown important crop in mid altitude areas of intensive maize-based cropping system of western Ethiopia. Agronomic management is the most important input for getting potential yield and high net returns in hybrid maize production. A field experiment was carried out on farmers' field to find out the effect of varieties (four maize) and nitrogen fertilizer rate $\left(55,110 \mathrm{~kg} \mathrm{~N} \mathrm{ha}^{-1}\right)$ with one control on yield components and nitrogen use efficiency of different maize varieties in 2013 and 2014 cropping season. It was laid with randomized complete block design in factorial arrangement with three replications. Mean grain yield, thousand seed weight, dry biomass and harvest index of maize varieties were significantly differed among farms and varieties of maize. Application of nitrogen fertilizer rates was significantly increased mean grain yield maize varieties. Interaction of maize varieties with nitrogen fertilizer rates was significantly affected all yield components of maize varieties. Application half and full recommended nitrogen fertilizer gave mean grain yield advantages of 31 and $41 \%$ over control maize varieties planted without nitrogen application. Maize varieties producing higher mean grain yield was also giving higher mean dry biomass. Mean nitrogen up take was varied from 225 to $357 \mathrm{~kg}$ $\mathrm{ha}^{-1}$ among varieties of maize. Higher agronomic efficiency of all maize varieties was obtained from maize planted with application half recommended nitrogen fertilizer compared to full recommend. Agronomic efficiency was ranged from 18 to 33 produced among maize varieties. Significantly higher nitrogen up take efficiency of maize varieties was achieved from maize planted with full recommended nitrogen fertilizer application. Considerably higher nitrogen use efficiency of maize varieties was realized from all maize varieties planted with application half recommended nitrogen fertilizer. Application of half recommended nitrogen fertilizer was gave $32 \%$ fertilizer $\mathrm{N}$ use efficiency advantage as compared to full recommended nitrogen fertilizer. Maize varieties BH-661>BH-660> BH-543> BH-540>BH- 
140 were desirable varieties for further promotion work and use by smallholder farmers in mid altitude area of western Ethiopia.

Key words: nitrogen, $\mathrm{N}$ accumulation, nitrogen use efficiency, variety, maize.

\section{Introduction}

Maize is the most widely cultivated crop in sub-Saharan Africa (SSA), and one of the few crops that have profound effects on the livelihoods of millions of people there. Nitrogen $(\mathrm{N})$ is an essential nutrient and constituent of 3-4\% dry matter [1], important constituent of many biomolecules in plants [2] and low $\mathrm{N}$ often becomes a limiting factor plant growth and development [3-5]; to high yields in a variety of agricultural systems [6]. Increased crop productivity has been associated with a 20 -fold increase in the global use of $\mathrm{N}$ fertilizer use during the past five decades [7] and this is expected to increase at least 3-fold by 2050 [8]. Dobermann [9] reported nitrogenous fertilizers widely applied by farmers and have contributed to remarkable increase in plant production during the past 50 years. Staple crops such as, maize is highly responsive to $\mathrm{N}$ and requires large quantity of $\mathrm{N}[10,11]$. Moose et al. [11] reported five million tons of $\mathrm{N}$ fertilizer used annually to fields of maize production in the industrialized world, and use is on the rise in developing nations. Nitrogen $(\mathrm{N})$ fertilizer is the most expensive input for cereal production worldwide. The world demand for nitrogen fertilizer in 2001 was 105.348 million tons and predicted to grow $1.7 \%$ annually for 2011-2015 [12].

Gallais and Hirel [2] reported that the worldwide output of chemical fertilizers has steadily raises from 33 TG in 1961 to 180 TG in 2007. N was accounted for about $58 \%$, while $\mathrm{P}$ was accounted for $24 \%$ and $\mathrm{K} 18 \%$ of the total chemical fertilizer production [2]. Therefore, Nitrogen is considered a strong tool for high crop yield [2,13]. Looking for varieties with efficient use of nitrogen is of paramount importance. N-use efficiency (NUE) is defined as grain production per unit of $\mathrm{N}$ applied to soil/available in soil [14]. Grain NUE can be more thoroughly expressed as the product of $\mathrm{N}$-uptake efficiency ( $\mathrm{N}$ uptake per unit available soil $\mathrm{N}$ ) and $\mathrm{N}$ utilization efficiency (grain production per unit absorbed $\mathrm{N}$ ) [15]. Using ${ }^{15} \mathrm{~N}$ approach Ma and Dwyer [16] showed that a high ratio of the amount of ${ }^{15} \mathrm{~N}$ recovered in a grain or Stover to the amount of fertilizer ${ }^{15} \mathrm{~N}$ applied to the soil) was primarily associated with greater $\mathrm{N}$-uptake and improved dry matter production during the grain filling 
period. Worldwide, nitrogen use efficiency (NUE) for cereal production is approximately 33 $\%$ [17]. Identification of maize varieties with greater $\mathrm{N}$ use efficiency would make a great contribution to smallholder farmers for sustainable maize production in the region. NUE in cropping system depends on the applied $\mathrm{N}$ and plant $\mathrm{N}$ uptake. Exploring NUE maize varieties helps to understand the rate of $\mathrm{N}$ applied in relation with crop $\mathrm{N}$ requirement. Furthermore, understanding the efficient NUE maize varieties help to reduce the $\mathrm{N}$ fertilizer cost and loss to the environment. Thus, the objective is to determine better nitrogen use efficiency and yield of maize varieties for sustainable maize production in mid altitude areas of western Ethiopia.

\section{Materials and methods}

The experiment was conducted on six farmers' field around Bako Tibe in 2013 and 2014 cropping seasons. The area lies between $8^{\prime} 59^{\prime} 31^{\prime \prime} \mathrm{N}$ to $9^{\prime} 01^{\prime} 16 \mathrm{~N}$ latitude and $37^{\circ} 13^{\prime} 29 \mathrm{E}$ to $37^{\circ} 21$ 'E longitude and at an altitude ranged from 1727 to 1778 meter above sea level, receiving mean annual rainfall of 1265 to $1293 \mathrm{~mm}$ with unimodal distribution [18,19]. It has a warm humid climate with the mean minimum, mean maximum and average air temperatures of $13.4,28.49$ and $20.95^{\circ} \mathrm{C}$, respectively [18] to $14,28.5$ and $21.2{ }^{\circ} \mathrm{C}$ [19]. The soil type is brown clay loam Alfisol [20]. The experiment was laid out in factorial combinations with complete block design in three replications. Five maize varieties from subhumid mid altitude area were used as main factors. Two level of nitrogen [ half of the recommended (55 $\left.\mathrm{Kg} \mathrm{N} \mathrm{ha}^{-1}\right)$ and recommended $\left(110 \mathrm{Kg} \mathrm{N} \mathrm{ha}^{-1}\right)$ will be used as sub factor. One maize variety (BH-543) without fertilizer was used as control treatments. The maize varieties were $\mathrm{BH}-540, \mathrm{BH}-543, \mathrm{BH}-661, \mathrm{BH}-660$ and $\mathrm{BH}-140)$. The total treatment combinations were 11 . The plot size was $5.1 \mathrm{~m}$ x $4.5 \mathrm{~m}$. An improved seed each variety was planted in rows spaced at $75 \mathrm{~cm}$ between rows and $30 \mathrm{~cm}$ between plants. The weighed nitrogen rate was applied half at planting and remaining half at knee height. One hundred kilogram per hectare of diammonium phosphate (DAP) was applied for all treatments uniformly during planting. All other agronomic management practices were applied as per recommendation for the variety. The necessary data were collected at right time and crop growth stage. 
Soil sampling and analysis: The soil samples was before treatment application from 10 sites randomly and composited one for analysis. The collected soil analysis were prepared following standard procedures and analyzed at Holleta and Debre Zite Agricultural Research Center Soil and Plant Analysis Laboratory. Determination of soil particle size distribution was carried out using the hydrometer method [21]. The soil $\mathrm{pH}$ was measured with digital $\mathrm{pH}$ meter potentiometrically in the supernatant suspension of 1:2.5 soils to distilled water ratio. Organic carbon was determined following wet digestion methods as described by [22] whereas kjeldahl procedure was used for the determination of total nitrogen $(\mathrm{N})$ as described by [23]. The available $\mathrm{P}$ was measured by Bray II method [24] and available potassium (K) was measured by flame photometry. The steam distillation method was used for determination of $\mathrm{NO}_{3}$ and $\mathrm{NH}_{4}$ as described by [25].

Crop parameters: grain yield thousand seed weight, and dry biomass and harvest index after maturity and harvesting of maize. The grain yield were harvested from the net plot (3 m x $5.1 \mathrm{~m}=15 \mathrm{~m}^{2}$ ). The harvested grain yield was adjusted to $12.5 \%$ moisture level [26, 27]. The adjusted seed yield at $12.5 \%$ moisture level per plot was converted to grain yield as kilogram per hectare.

Plant tissue sampling and analysis: The tissue of maize was collected at $50 \%$ tasseling of maize from three replications and composited to after chopping. The grain of maize was collected after harvesting of the crop. The collected tissue and grain was prepared following standard procedures and analyzed at Holleta and Debre Zite Agricultural Research Center Soil and Plant Analysis Laboratory. The maize tissues and grain were subjected to wet digestion (Jones and Case1990). The $\mathrm{N}$ content of the plant tissue was determined by Kjeldahl procedure, whereas the $\mathrm{P}$ content was determined by colorimeterically according to [28].

Total $\mathrm{N}$ uptake was calculated as $=$ nutrient concentration $\mathrm{x}$ dry biomass weight $\left(\mathrm{kg} \mathrm{ha}^{-1}\right)$ of maize. Nitrogen agronomic efficiency (NAE), which is defined as the efficiency of converting applied $\mathrm{N}$ to grain yield (Wu et al, 2011). Agronomic efficiency is calculated as the amount of harvestable product, i.e. $\mathrm{kg}$ of cereal per $\mathrm{kg}$ of applied nutrient (N) [29].

$N A E(k g \operatorname{grain} / k g N)=\frac{\left(Y_{N}-Y_{\mathrm{O}}\right)}{F_{N}}$ 
Where $\mathrm{Y}_{\mathrm{N}}$ and $\mathrm{Y}_{0}$ are the grain yield with and without $\mathrm{N}$ applied, respectively; and $\mathrm{FN}$ is the amount of $\mathrm{N}$ fertilizer applied.

The $\mathrm{N}$ uptake efficiency (UEN) is the total amount of $\mathrm{N}$ absorbed (including that present in the roots, often disregarded) per $\mathrm{kg}$ of applied $\mathrm{N}$.

$$
U E N\left(k g N / k g N=\frac{U_{N}-U_{0}}{F_{N}}\right.
$$

Plant nitrogen use efficiency/ physiological efficiency is calculated as total dry matter or grain yield produced per unit of $\mathrm{N}$ absorbed. $\mathrm{N}$ utilization efficiency was calculated as described by [30].

$$
P E N\left(k g \text { grain/ } k g N=\frac{Y_{N}-Y_{0}}{U_{N}-U_{0}}\right.
$$

Apparent fertilizer $\mathrm{N}$ use (recovery) efficiency (ANRE) is the amount of fertilizer $\mathrm{N}$ taken up by the plant per kg of $\mathrm{N}$ applied as fertilizer. Apparent $\mathrm{N}$ fertilizer recovery (ANRE) was calculated as it is described by [29,31].

$\%$ fertilizer nutrient recovery $(\mathrm{ANRE})=\frac{(T N F)-(T N U)}{R} X 100$

The data analyses for agronomic data were carried out using statistical packages and procedures of SAS computer software [32]. Mean separation was done using least significance difference (LSD) procedure at $5 \%$ probability level [33].

\section{Results and discussion}

\subsection{Some soil chemical and physical properties of study area}

The result of soil chemical and physical properties of different farm field's soil has been indicated in Table 1. All the six-farm soil was clay in textural classes. The soil $\mathrm{pH}$ in $\mathrm{H}_{2} \mathrm{O}$ was ranged from 4.63 to 5.45. This implies that the soil reaction all six farms were found in very strongly acidic to moderately acidic range $[34,35]$. Sound soil management practices are required to use this soil for sustainable crop production.

Total $\mathrm{N}$ and $\mathrm{P}$ were ranged from 0.17 to $0.23 \%$; and 4.18 to $7.52 \mathrm{ppm}$ (Table 1 ). The total $\mathrm{N}$ concentrations for all six farms were found in very low, medium to high range [3436]. In Alfisol the total $\mathrm{N}$ was in medium range the amount of $\mathrm{N}$ required to amend the soil and have a high potential for maize production. 
Table 1. Some physicochemical properties soil of farmer's field before planting maize in Bako-Tibe districts, western Ethiopia

\begin{tabular}{|c|c|c|c|c|c|c|c|c|c|c|c|c|}
\hline \multirow[t]{2}{*}{ Farms } & \multirow[t]{2}{*}{ pH } & \multirow{2}{*}{$\begin{array}{c}N \\
(\%)\end{array}$} & \multirow{2}{*}{$\begin{array}{l}\mathbf{P} \\
(\mathbf{p p m})\end{array}$} & OC & OM & CEC & $\mathbf{K}$ & $\mathbf{N a}$ & \multirow{2}{*}{$\begin{array}{l}\text { Exch. } \\
\text { acidity }\end{array}$} & $\mathrm{N0}_{3}-\mathrm{N}$ & $\mathrm{NH}_{4}+\mathrm{N}$ & \multirow[t]{2}{*}{ Texture } \\
\hline & & & & \multicolumn{2}{|c|}{$\%$} & \multicolumn{3}{|c|}{$($ meq $100 \mathrm{~g}$ soil-1) } & & \multicolumn{2}{|c|}{$(\mathbf{p p m})$} & \\
\hline F-1 & 4.86 & 0.22 & 5.02 & 2.69 & 4.63 & 21.26 & 0.71 & 1.68 & 0.09 & 43.98 & trace & Clay \\
\hline F-2 & 4.63 & 0.22 & 5.43 & 2.53 & 4.35 & 19.7 & 0.13 & 2.4 & 0.17 & 53.05 & 8.84 & Clay \\
\hline F-3 & 5.45 & 0.23 & 7.52 & 2.77 & 4.76 & 21.32 & 0.85 & 2.4 & 0.17 & 41.13 & 8.81 & Clay \\
\hline F-4 & 5.4 & 0.17 & 6.27 & 2.07 & 3.56 & 38.12 & 0.85 & 1.68 & 0.08 & 30.17 & 6.03 & Clay \\
\hline F-5 & 4.71 & 0.2 & 4.18 & 2.46 & 4.23 & 22.74 & 0.99 & 2.16 & 0.24 & 66.38 & 9.05 & Clay \\
\hline F-6 & 5.44 & 0.18 & 5.67 & 2.22 & 3.82 & 36.5 & 0.56 & 1.44 & 0.12 & 41.13 & 11.75 & Clay \\
\hline
\end{tabular}

Farm1-6= farmers name Takele uluma, Adisu Fufa, Adisu Likessa, Mulatu shukar, Tesfaye Tsagaye and Gutu Tolera.

The extractable phosphorus concentration of was found in low to medium range $[34,35]$. The lower and medium extractable soil $\mathrm{P}$ content of different farms was a good indicator of the soil P supply for agricultural maize production in different soils scenarios of various farm fields. The different farm fields were needs different rates of nitrogen and phosphorous fertilizer management practices to get the potential yield of maize. The organic carbon and organic matter concentrations were ranged 2.07 to 2.77 and 3.56 to $4.76 \%$ which is found low to medium range [34-35]. The nutrient retention capacity of the six farm soil was very low, low to medium and low in microbial population. The CEC concentration was ranged from 19.7 to $38.5 \mathrm{cmol}^{+} \mathrm{kg}^{-1}$ and found in medium to high range [34, 35]. Horneck et al. [37] soils with high clay and/or organic matter content have high CEC. The NO3-N concentration of the six farm soil was ranged between 30.17 to $66.38 \mathrm{ppm}$ (Table 7.1), found in high to very high range [38, 39]; excessive range [40]. The NH4-N concentration of the soil was ranged from trace to $11.75 \mathrm{ppm}$ (Table 1) found in optimum range [37]. The $\mathrm{NO}_{3}-\mathrm{N}$ and $\mathrm{NH}_{4}+\mathrm{N}$ concentration of the soils were found in optimum range for sustainable maize production. Therefore, lower input of nitrogen fertilizer was recommended for sustainable maize production in mid altitude agroecology of Bako Tibe districts.

\subsection{Mean grain yield and thousand seed weight of maize}

Summarized mean grain yield and thousand seed weight of maize was presented in Table 2 and 3. Mean grain yield of maize was significantly different among varieties, across farms and combined over farms (Table 2). 
Table 2. Effects of varieties and nitrogen rate on mean number of grain yield and thousand seed weight of maize on farmer's field around Bako Tibe, western Ethiopia

\begin{tabular}{|c|c|c|c|c|c|c|c|c|c|c|c|c|}
\hline \multirow[t]{3}{*}{ Varieties } & \multicolumn{6}{|c|}{ Grain yield $\left(\mathrm{kg} \mathrm{ha}^{-1}\right)$} & \multicolumn{6}{|c|}{ Thousand seed weight (g) } \\
\hline & \multicolumn{3}{|c|}{2013} & \multicolumn{3}{|c|}{2014} & \multicolumn{3}{|c|}{2013} & \multicolumn{3}{|c|}{2014} \\
\hline & F- 1 & F- 2 & F-3 & F-4 & F-5 & F-6 & F- 1 & F- 2 & F-3 & F-4 & F-5 & F-6 \\
\hline BH-540 & 4114 & 2089 & 4751 & 2655 & 4518 & 5282 & 382 & 419 & 426 & 399 & 442 & 450 \\
\hline BH-543 & 4988 & 2566 & 4644 & 2999 & 3731 & 4372 & 431 & 383 & 434 & 403 & 388 & 409 \\
\hline ВН- 661 & 6546 & 3050 & 4691 & 4193 & 5643 & 6052 & 413 & 372 & 418 & 377 & 410 & 384 \\
\hline ВH-660 & 3216 & 2509 & 4425 & 3447 & 4972 & 5867 & 321 & 388 & 436 & 428 & 366 & 461 \\
\hline BH-140 & 4113 & 1754 & 4878 & 3171 & 4411 & 4223 & 366 & 336 & 372 & 430 & 397 & 392 \\
\hline BH-543 & 3796 & 1870 & 3659 & 3941 & 3350 & 1556 & 341 & 307 & 406 & 356 & 421 & 365 \\
\hline $\operatorname{LSD}(\%)$ & 841.3 & 176.7 & 349.1 & 178.7 & 327.9 & 549.58 & 66.41 & 79.68 & 46.15 & 27.31 & 59.66 & 48.65 \\
\hline CV (\%) & 15.54 & 6.07 & 6.27 & 5.84 & 5.81 & 8.71 & 14.31 & 17.3 & 9.12 & 14.58 & 12.27 & 9.56 \\
\hline \multicolumn{13}{|l|}{$\mathrm{N}\left(\mathrm{kg} \mathrm{ha}^{-1}\right)$} \\
\hline $50 \% \mathrm{RR}$ & 4705 & 2208 & 4397 & 3159 & 4535 & 4806 & 389 & 361 & 419 & 386 & 409 & 424 \\
\hline $100 \% \mathrm{RR}$ & 4485 & 2579 & 4958 & 3427 & 4774 & 5513 & 376 & 399 & 415 & 429 & 392 & 414 \\
\hline Control & 3796 & 1870 & 3659 & 3941 & 3350 & 1556 & 341 & 307 & 406 & 356 & 421 & 365 \\
\hline $\operatorname{LSD}(\%)$ & 532.07 & 111.7 & 220.7 & 147.5 & 207.4 & 347.59 & NS & 79.68 & Ns & NS & NS & NS \\
\hline $\mathrm{CV}(\%)$ & 15.54 & 6.07 & 6.27 & 5.84 & 5.81 & 8.71 & 14.31 & 17.3 & 9.12 & 22.2 & 12.27 & 9.56 \\
\hline
\end{tabular}

F-1-F6= farmers name (Takele Uluma, Adisu Fufa, Adisu Likessa, Mulatu Shukar, Tesfaye Tsagaye and Gutu Tolera), NS=Non-significant difference at $5 \%$ probability level, $50 \%$ and $100 \% \mathrm{RR}=$ half and full doses (55 and $110 \mathrm{~kg} \mathrm{~N} \mathrm{ha}^{-1}$ ) recommended for maize.

Significantly higher mean yield was collected from farm 6, farm 3, farm1, farm5, farm 4 and farm 2 in descending order respectively. This indicates there were variations among farmers field with fertility status and management system applied to maize too. Raun et al. [41] reported indigenous soil $\mathrm{N}$ across the landscape can vary several-fold, resulting in very different $\mathrm{N}$ recommendations depending on the location within the field. This indeed justifies the need site-based fertilizer management and variety recommendation to farmers for sustainable maize production in the agroecology. Different varieties gave different yield across farms. Maize varieties BH-661> BH-660> BH-540 > BH-543> BH-140 in order produced better mean grain yield. All varieties were produced significantly higher mean grain yield as compared maize varieties planted without nitrogen fertilizer application. Combined mean grain yield advantage of 24.07, 28.19, 28.79, 3.47 and $66.03 \%$ were achieved from BH-140, BH-543, BH-540, BH-660 and BH-661 maize varieties as compared variety planted without nitrogen (Table 2). BH-661 followed by BH-660 was significantly produced higher combined mean grain yield maize and recommended for farmers to 
produced higher mean grain yield in area. Farmers should use maize varieties BH-661>BH660> BH-540> BH-543> BH-140, importance in descending order for alternative options.

Mean grain yield of maize varieties was significantly influenced by application nitrogen rates (Table 2). Significantly higher mean grain yield was harvested from maize varieties planted with application of full recommended $\left(110 \mathrm{~kg} \mathrm{~N} \mathrm{ha}^{-1}\right)$ nitrogen rate compared to half nitrogen rate. Higher mean grain yield of maize varieties was obtained from half and full recommended nitrogen fertilizer applied as compared maize variety planted without nitrogen in all farms except farm 4. This indicates maize planted in farm 4 was not responding nitrogen fertilizer application which might be due to very poor fertility status of the soil and termite infestation problems observed in the farm. Higher mean grain yield advantage of $18.07,20.17,23.95,35.37$, and $208.87 \%$ were obtained from farm2, farm3, farm1, farm5 and farm6, respectively with half recommended nitrogen as compared to maize variety planted without nitrogen (Table 2). Maize varieties planted with full recommended (110 $\left.\mathrm{kg} \mathrm{N} \mathrm{ha}^{-1}\right)$ were gave significantly higher mean grain yield advantages of 18.15, 35.50, 37.91, 42.51 and $254.31 \%$ from farm1, farm3, farm2, farm5 and farm6 as compared to maize variety planted without nitrogen fertilizer (Table 2). Combined mean grain yield advantages of 31 and 41.60 $\%$ across farms were produced from maize planted with half and full recommended nitrogen applied as compared to maize varieties planted without nitrogen. Furthermore, application of full recommended nitrogen across farms gave grain yield advantage of $8.09 \%$ as compared maize planted with half recommended nitrogen applied.

Maize varieties were revealed significantly difference in thousand seed weight among farms and combined across farms (Table 2). Significantly higher thousand seed weights were obtained from BH-540, BH-5443, BH-660, BH-661 and $\mathrm{BH}-140$ in descending order, respectively across farms (Table 2). This indicates different varieties were varied in seed size and carbohydrate accumulation in the seed coats. Application of nitrogen was nonsignificantly influenced mean thousand seed weight of maize varieties across farms (Table 2).

Interaction maize varieties with nitrogen rate were significantly affected mean grain yield of maize among farms and combined across farms to (Table 3). This is implying that the responses of different maize varieties to rates of $\mathrm{N}$ fertilizer were different. Le Gouis et al. [42] confirmed that there is a genetic variability for grain yield at a low $\mathrm{N}$ level and that the genotype $\mathrm{x} \mathrm{N}$ level interaction is significant. 
Table 3. Combination effects of varieties and nitrogen rate on mean grain yield and thousand seed weight of maize on farmer's field around Bako Tibe, western Ethiopia

\begin{tabular}{|c|c|c|c|c|c|c|c|c|c|c|c|c|}
\hline \multirow{3}{*}{$\begin{array}{c}\text { Maize varieties } \\
\text { with N rates }\end{array}$} & \multicolumn{6}{|c|}{ Grain yield (kg ha-1) } & \multicolumn{6}{|c|}{ Thousand seed weight (g) } \\
\hline & \multicolumn{3}{|c|}{2013} & \multicolumn{3}{|c|}{2014} & \multicolumn{3}{|c|}{2013} & \multicolumn{3}{|c|}{2014} \\
\hline & F- 1 & F- 2 & F-3 & F-4 & F-5 & F-6 & F- 1 & F- 2 & F-3 & F-4 & F-5 & F-6 \\
\hline BH-540(50\%RR) & 3633 & 1894 & 5057 & 2613 & 3904 & 4880 & 400 & 389 & 438 & 384 & 468 & 454 \\
\hline BH-540(100 \%RR) & 4595 & 2283 & 4446 & 2696 & 5132 & 5684 & 364 & 449 & 414 & 414 & 417 & 447 \\
\hline BH-543(50\%RR) & 4516 & 2455 & 4141 & 2990 & 4043 & 4383 & 437 & 391 & 460 & 387 & 393 & 408 \\
\hline BH-543(100\%RR) & 5459 & 2678 & 5147 & 3009 & 3419 & 4361 & 425 & 374 & 408 & 420 & 384 & 411 \\
\hline BH-661(50\%RR) & 6719 & 2628 & 4323 & 4457 & 5472 & 5556 & 406 & 335 & 407 & 382 & 444 & 396 \\
\hline BH-661(100 \%RR) & 6373 & 3472 & 5060 & 3928 & 5814 & 6548 & 421 & 408 & 429 & 373 & 377 & 372 \\
\hline BH- 660(50 \%RR) & 3872 & 2567 & 4107 & 3432 & 5042 & 5155 & 322 & 341 & 404 & 352 & 365 & 484 \\
\hline BH-660(100 \%RR) & 2561 & 2451 & 4742 & 3462 & 4902 & 6579 & 319 & 436 & 467 & 503 & 366 & 437 \\
\hline BH-140(50 \%RR) & 4788 & 1494 & 4359 & 2302 & 4216 & 4053 & 379 & 346 & 388 & 426 & 378 & 381 \\
\hline BH-140(100 \%RR) & 3437 & 2013 & 5398 & 4039 & 4605 & 4393 & 353 & 326 & 356 & 435 & 417 & 403 \\
\hline ВН-543 & 3796 & 1870 & 3659 & 3941 & 3350 & 1556 & 341 & 307 & 406 & 356 & 421 & 365 \\
\hline $\operatorname{LSD}(5 \%)$ & 1154.8 & 242.2 & 537.8 & 361 & 456.19 & 960.75 & 88.794 & NS & 81.67 & 147.33 & NS & 65.55 \\
\hline $\mathrm{CV}(\%)$ & 15.41 & 6.05 & 7.01 & 6.33 & 5.9 & 11.45 & 13.76 & 17.21 & 11.52 & 21.48 & 12.25 & 9.288 \\
\hline
\end{tabular}

F-1-F6= Farmers name (Takele Uluma, Adisu Fufa, Adisu Likessa, Mulatu Shukar, Tesfaye Tsagaye and Gutu Tolera), $\mathrm{NS}=$ Non-significant difference at $5 \%$ probability level, $50 \%$ and $100 \% \mathrm{RR}=$ half and full doses $\left(55\right.$ and $\left.110 \mathrm{~kg} \mathrm{~N} \mathrm{ha}^{-1}\right)$ recommended for maize. 
Average mean grain yield of 2346, 3352, 4523, 4536, 4585 and $4832 \mathrm{~kg} \mathrm{ha}^{-1}$ were obtained from farm2, farm4, farm1, farm5 farm 3 and farm 6, respectively (Table 3). This indicates variation of soil fertility status and management practices applied among each farm. Farm and/or soil test-based fertilizer recommendations were required for sustainable maize production in the area. Maize varieties planted with half $\left(55 \mathrm{~kg} \mathrm{~N} \mathrm{ha}^{-1}\right)$ recommended nitrogen application were gave mean grain yield advantages of 16.71, 20.93, 23.97, 33.01 and $60.42 \%$ from BH-140, BH-540, BH-543, BH-660 and BH-661 as compared maize planted without nitrogen application. BH-543, BH-660 and $\mathrm{BH}-661$ varieties were better nitrogen efficient varieties among maize varieties used. Significantly higher mean grain yield advantages of $31.43,32.45,35.89,36.65$ and $71.64 \%$ were produced from maize varieties (BH-140, BH-543, BH-660, BH-540 and BH-661) planted with full (110 kg N ha-1) recommended nitrogen fertilizer as compared to maize variety planted with nitrogen. The grain yield of maize was increased as the rate of nitrogen fertilizer increased (Moser, 2004). Maize varieties BH-661 followed BH-660 were ranked first and second among the maize varieties used. Higher mean grain yield and nitrogen use efficiency were obtained from $\mathrm{BH}-$ 661 followed BH-660 varieties of maize. This indicates maize varieties with higher grain yield potential had higher nitrogen use efficiency.

Thousand seed weight of maize was significantly influenced by interaction of maize varieties with nitrogen rates applied (Table 3). Mean thousand seed weight ranged between 373 to $416 \mathrm{~g}$ among farms. Combined mean across farms, thousand seed weight ranged between 366 to $422 \mathrm{~g}$. The lowest thousand seed weight was obtained from maize varieties planted without nitrogen application. Different maize varieties were gave varied mean thousand seed weight with nitrogen rate application. BH-661 and BH-660 were gave higher mean thousand seed weight with full recommended nitrogen application as compared to other maize varieties which vise verse with nitrogen application.

\subsection{Mean dry biomass and harvest index of maize}

The summarized analysis mean results of dry biomass and harvest index of maize varieties are presented in Table 4 and 5. Significant differences were observed among maize varieties on mean dry biomass across farms and between varieties (Table 4). Significantly higher mean dry biomass of 9912, 11684, 14015, 16110 and $18647 \mathrm{~kg} \mathrm{ha}^{-1}$ were collected 
from farm2, farm6, farm5, farm1 and farm 6 planted maize varieties. All maize varieties were produced higher combined mean dry biomass as compared to maize varieties planted without nitrogen fertilizer. Mean dry biomass was ranged from 1361 to $21230 \mathrm{~kg}$ ha-1 received from BH-540 and BH-661 (Table 4).

Significantly higher mean dry biomass advantages of 23.43, 26.64, 42.29, 48.84 and $92.48 \%$ as compared maize variety planted without nitrogen were obtained from $\mathrm{BH}-540$, BH-140, BH-660, BH-543 and BH-660 (Table 4). This justifies there were variations among maize varieties in dry matter accumulation and morphological growth. Application of nitrogen was non-significantly affected mean dry biomass of maize varieties (Table 4). Higher mean dry biomass was harvested from application of recommended (110 kg ha-1) nitrogen fertilizer as compared to maize planted with half recommended $\mathrm{N}$ and without nitrogen fertilizer application (Table 4). 
Table 4. Effects of varieties and nitrogen rate on mean number of dry biomass and harvest index of maize on farmer's field around Bako-Tibe, western Ethiopia

\begin{tabular}{|c|c|c|c|c|c|c|c|c|c|c|c|c|}
\hline \multirow[t]{3}{*}{ Varieties } & \multicolumn{6}{|c|}{ Dry biomass (kg ha-1) } & \multicolumn{6}{|c|}{ Harvest index (\%) } \\
\hline & \multicolumn{3}{|c|}{2013} & \multicolumn{3}{|c|}{2014} & \multicolumn{3}{|c|}{2013} & \multicolumn{3}{|c|}{2014} \\
\hline & F- 1 & F- 2 & F-3 & F-4 & F-5 & F-6 & F- 1 & F- 2 & F-3 & F-4 & F-5 & F-6 \\
\hline BH-540 & 14648 & 6406 & 20881 & 12170 & 10362 & 17220 & 31.23 & 40.15 & 23.96 & 20.75 & 46.50 & 30.98 \\
\hline BH-543 & 20285 & 12071 & 20967 & 12299 & 10300 & 22577 & 27.59 & 22.27 & 22.73 & 24.91 & 37.96 & 19.89 \\
\hline ВН- 661 & 21874 & 14041 & 24559 & 18915 & 14171 & 33822 & 31.50 & 22.86 & 20.73 & 24.97 & 43.70 & 18.32 \\
\hline ВН-660 & 13868 & 10247 & 17723 & 12030 & 12829 & 27473 & 24.94 & 24.88 & 25.06 & 30.87 & 46.48 & 22.25 \\
\hline BH-140 & 15752 & 7895 & 17072 & 13824 & 13338 & 15928 & 27.11 & 24.92 & 29.90 & 24.33 & 35.84 & 27.04 \\
\hline BH-543 & 10232 & 8811 & 10677 & 14853 & 9101 & 12505 & 40.82 & 23.41 & 37.18 & 25.23 & 36.56 & 13.38 \\
\hline $\operatorname{LSD}(\%)$ & 5748 & 2318.3 & NS & 1757.8 & NS & 6376.8 & NS & 3.2231 & NS & 2.0001 & 3.882 & 4.1353 \\
\hline CV (\%) & 25.87 & 14.62 & 16.47 & 20.22 & 12.29 & 21.44 & 29.23 & 14.32 & 16.59 & 18.990 & 11.92 & 15.35 \\
\hline \multicolumn{13}{|l|}{$\mathrm{N}\left(\mathrm{kg} \mathrm{ha}^{-1}\right)$} \\
\hline $50 \% \mathrm{RR}$ & 17560 & 9255 & 20389 & 12535 & 11979 & 22267 & 28.06 & 28.06 & 23.24 & 25.92 & 40.22 & 23.25 \\
\hline $100 \% \mathrm{RR}$ & 17011 & 11009 & 20092 & 15160 & 12420 & 24540 & 28.89 & 25.98 & 25.71 & 24.42 & 43.98 & 24.14 \\
\hline Control & 10232 & 8811 & 10677 & 14853 & 9101 & 12505 & 40.82 & 23.41 & 37.18 & 25.23 & 36.56 & 13.38 \\
\hline $\operatorname{LSD}(\%)$ & NS & NS & NS & NS & NS & NS & 5.746 & NS & NS & NS & NS & NS \\
\hline $\mathrm{CV}(\%)$ & 25.87 & 14.62 & 16.47 & 22.17 & 12.29 & 21.44 & 29.23 & 14.32 & 16.59 & 14.5 & 11.92 & 15.35 \\
\hline
\end{tabular}

F-1-F6=farmers name (Takele Uluma, Adisu Fufa, Adisu Likessa, Mulatu Shukar, Tesfaye Tsagaye and Gutu Tolera), NS= Non-significant difference at $5 \%$ probability level, $50 \%$ and $100 \% \mathrm{RR}=$ half and full doses $\left(55\right.$ and $\left.110 \mathrm{~kg} \mathrm{~N} \mathrm{ha}^{-1}\right)$ recommended for maize. 
Interaction of varieties by nitrogen rates were significantly affected mean dry biomass of maize across farms and among varieties (Table 5). Mean dry biomass of maize varieties were ranged from 10012 to $22413 \mathrm{~kg} \mathrm{ha}^{-1}$, which received from farm 2 and farm 6 (Table 5). All maize varieties were produced significantly higher mean dry biomass with application of half and recommended nitrogen fertilizer as compared to maize variety planted without nitrogen fertilizer (Table 5). At half recommended and full recommended nitrogen application mean dry biomass advantages ranged from 17.13 to $92.21 \%$ and 25.58 to 92.75 $\%$ as compared maize variety planted without nitrogen application. Anbessa and Juskiw [43] stated high biomass is the result of the plant's internal efficiency to utilize the $\mathrm{N}$ taken-up to produce dry matter and there is a direct relationship between biomass and $\mathrm{N}$ utilization efficiency. Dry Biomass is certainly an important component of grain yield and NUE in all grain crops [44]. Lemaire et al. [45] reported high above-ground biomass is often associated with a well-developed root system and more $\mathrm{N}$ uptake. Gava et al. [46] found increase in dose of nitrogen fertilizer caused increase in dry matter and dry matter production rate in corn. Nitrogen fertilizer promoted increase $79.5 \%$ in shoot dry matter production of corn plants as compared to without fertilizer treatment [47]. This revealed application of nitrogen was very crucial for improved maize varieties production in the agroecology.

Main effects varieties were significantly affected mean harvest index of maize varieties at farm 2, farm4, farm5 and farm 6 (Table 4). Across farms, mean harvest index of maize varieties was ranged from 21.98 to $41.17 \%$, which received from farm 6 and farm 5 . Higher mean harvest index was harvested from BH-540 followed by BH-660 and BH-140, respectively. Application of nitrogen rates were non-significantly affected mean harvest index maize varieties across each farms except farm 1.

Interaction of maize varieties by nitrogen rates were significantly affected mean harvest index maize varieties (Table 5). Across farm mean harvest index were ranged from 23 to $42 \%$, which received from farm 6 and farm 5. Application of nitrogen fertilizer at half and recommended fertilizer rate were gave significantly higher mean harvest index as compared maize varieties planted without fertilizer application. 
Table 5. Combination effects of varieties and nitrogen rate on mean number of dry biomass and harvest index of maize on farmer's field around Bako Tibe, western Ethiopia

\begin{tabular}{|c|c|c|c|c|c|c|c|c|c|c|c|c|}
\hline \multirow{3}{*}{$\begin{array}{l}\text { Maize varieties } \\
\text { with N rates }\end{array}$} & \multicolumn{6}{|c|}{ Dry biomass $\left(\mathrm{kg} \mathrm{ha}^{-1}\right)$} & \multicolumn{6}{|c|}{ Harvest index (\%) } \\
\hline & \multicolumn{3}{|c|}{2013} & \multicolumn{3}{|c|}{2014} & \multicolumn{3}{|c|}{2013} & \multicolumn{3}{|c|}{2014} \\
\hline & F- 1 & F- 2 & F-3 & F-4 & F-5 & F-6 & F- 1 & F- 2 & F-3 & F-4 & F-5 & F-6 \\
\hline BH-540(50 \%RR) & 17684 & 4567 & 20650 & 11977 & 8212 & 17174 & 21.51 & 46.60 & 26.96 & 19.58 & 47.74 & 28.43 \\
\hline BH-540(100\%RR) & 11612 & 8246 & 21111 & 12363 & 12512 & 17266 & 40.95 & 33.70 & 20.95 & 21.91 & 45.26 & 33.54 \\
\hline BH-543(50 \%RR) & 13990 & 11228 & 21408 & 11225 & 9618 & 23378 & 33.90 & 24.40 & 19.61 & 27.00 & 44.99 & 19.31 \\
\hline BH-543(100\%RR) & 26580 & 12915 & 20525 & 13373 & 10981 & 21776 & 21.28 & 20.13 & 25.84 & 22.83 & 30.94 & 20.47 \\
\hline BH-661(50\%RR) & 21710 & 13538 & 27593 & 19258 & 14100 & 31007 & 33.43 & 19.49 & 15.63 & 24.19 & 40.93 & 18.41 \\
\hline BH-661(100\%RR) & 22038 & 14544 & 21526 & 18572 & 14241 & 36637 & 29.57 & 26.24 & 25.84 & 25.74 & 46.47 & 18.24 \\
\hline BH- $660(50 \% R R)$ & 16629 & 9825 & 16873 & 10583 & 14928 & 25258 & 24.04 & 25.93 & 24.63 & 32.81 & 33.74 & 21.43 \\
\hline BH-660(100 \%RR) & 11108 & 10669 & 18572 & 13476 & 10730 & 29688 & 25.84 & 23.82 & 25.48 & 28.93 & 59.22 & 23.08 \\
\hline $\mathrm{BH}-140(50 \% \mathrm{RR})$ & 17786 & 7120 & 15421 & 9632 & 13037 & 14520 & 27.41 & 23.85 & 29.36 & 25.99 & 33.70 & 28.70 \\
\hline BH-140(100\%RR) & 13718 & 8670 & 18723 & 18016 & 13639 & 17335 & 26.80 & 25.98 & 30.43 & 22.67 & 37.98 & 25.38 \\
\hline BH-543 & 10232 & 8811 & 10677 & 14853 & 9101 & 12505 & 40.82 & 23.41 & 37.18 & 25.23 & 36.56 & 13.38 \\
\hline $\operatorname{LSD}(5 \%)$ & 7729 & 3156.8 & 6003.80 & 6268.7 & 3530.3 & 8650.5 & 12.14 & 4.4077 & 5.70 & 6.1211 & 5.4303 & 5.8337 \\
\hline $\mathrm{CV}(\%)$ & 24.95 & 14.265 & 16.40 & 22.62 & 11.99 & 21.68 & 28.11 & 14.16 & 15.60 & 16.99 & 12.02 & 15.74 \\
\hline
\end{tabular}

F-1-F6= Farmers name (Takele Uluma, Adisu Fufa, Adisu Likessa, Mulatu Shukar, Tesfaye Tsagaye and Gutu Tolera), $\mathrm{NS}=$ Non-significant difference at $5 \%$ probability level, $50 \%$ and $100 \% \mathrm{RR}=$ half and full doses $\left(55\right.$ and $\left.110 \mathrm{~kg} \mathrm{~N} \mathrm{ha}^{-1}\right)$ recommended for maize. 
Mean harvest index advantages of $8.1 \%$ at half nitrogen and 5.5 and $11.2 \%$ at full recommended nitrogen application as compared maize varieties planted without nitrogen application were obtained from BH-540 and BH-660. This indicates application of nitrogen fertilizer was give more yield as compared to planting maize varieties without nitrogen fertilizer application. This justifies BH-540 and BH-660 had better response to applied nitrogen fertilizer. Improved nitrogen use efficiency by better varieties can be achieved by selecting for cultivars with high harvest index [48]. Therefore, application of optimum nitrogen fertilizer was very crucial for sustainable maize production. In conclusion planting of maize varieties with optimum nitrogen application was far most important for sustainable maize production.

\subsection{Nitrogen up take and agronomic efficiency of maize}

The nitrogen uptake and agronomic efficiency of maize varieties are indicated in Table 6. Nitrogen uptake of maize varieties was varied across farms and among varieties. Mean nitrogen uptake was ranged between $150-392 \mathrm{~kg} \mathrm{ha}^{-1}$ among farms. This indicates there is variation of farmers' field in nitrogen uptake of maize varieties. Higher nitrogen uptake of all maize varieties was obtained at full $\left(110 \mathrm{~kg} \mathrm{~N} \mathrm{ha}^{-1}\right)$ recommended nitrogen fertilizer application as compared to half recommended nitrogen fertilizer application. The $\mathrm{N}$ uptake in the aboveground biomass increased for all cultivars with the increase in rate of $\mathrm{N}$ fertilizer [49]. Heinrich et al. [50] reported $\mathrm{N}$ uptake was likely at its maximum for an $\mathrm{N}$ fertilizer rate of around $120 \mathrm{lb}$. N Acre ${ }^{-1}$ as compared to $80 \mathrm{lb}$. N Acre ${ }^{-1}$. Higher mean nitrogen uptake of $12,21,43,43$ and $97 \%$ were obtained at half recommended nitrogen application as compared to maize planted without fertilizer application from BH-140, BH-540, BH-660, and BH-543 and BH-661 varieties of maize (Table 6). At full recommended nitrogen fertilizer application mean nitrogen uptake of 32, 40, 55, 96 and 104 were obtained from BH-540, BH$660, \mathrm{BH}-140, \mathrm{BH}-543$ and $\mathrm{BH}-661$ as compared to maize variety planted without nitrogen fertilizer application. The use of cultivars with enhanced capacity to take up and utilize $\mathrm{N}$ would increase NUE [51]. Anbessa and Juskiw [49] reported the integration of improved N management practices and more efficient cultivars will bring about a significant improvement in NUE. Thus, considering higher nitrogen uptake of maize varieties was very crucial to have higher productivity of maize varieties. 
Table 6. Effects of varieties and nitrogen rate on nitrogen up take and agronomic efficiency of maize on farmer's field around Bako-Tibe, western Ethiopia

\begin{tabular}{|c|c|c|c|c|c|c|c|c|c|c|c|c|c|c|}
\hline \multirow{3}{*}{$\begin{array}{c}\text { Maize varieties with } \\
\qquad \mathrm{N} \text { rates }\end{array}$} & \multicolumn{7}{|c|}{ Nitrogen up take $\left(\mathrm{kg} \mathrm{ha}^{-1}\right)$} & \multicolumn{7}{|c|}{ Agronomic efficiency (kg grain kg N applied $^{-1}$ ) } \\
\hline & \multicolumn{3}{|c|}{2013} & \multicolumn{4}{|c|}{2014} & \multicolumn{3}{|c|}{2013} & \multicolumn{3}{|c|}{2014} & \multirow[t]{2}{*}{ Mean } \\
\hline & Farm 1 & Farm 2 & Farm 3 & Farm4 & Farm5 & Farm & Mean & Farm 1 & Farm 2 & Farm 3 & Farm 4 & Farm 5 & Farm 6 & \\
\hline BH-540(50 \%RR) & 324 & 77 & 285 & 187 & 113 & 306 & 215 & -2.96 & 0.44 & 25.42 & -24.15 & 10.07 & 60.44 & 11.54 \\
\hline BH-540(100 \%RR) & 199 & 178 & 265 & 240 & 233 & 294 & 235 & 7.26 & 3.75 & 7.15 & -11.32 & 16.20 & 37.53 & 10.10 \\
\hline BH-543(50 \%RR) & 266 & 153 & 392 & 197 & 190 & 330 & 255 & 13.09 & 10.64 & 8.76 & -17.29 & 1.26 & 51.40 & 11.31 \\
\hline BH-543(100 \%RR) & 599 & 247 & 329 & 290 & 207 & 414 & 348 & 15.12 & 7.35 & 13.53 & -8.47 & 6.31 & 25.50 & 9.89 \\
\hline BH-661(50 \%RR) & 398 & 197 & 448 & 267 & 216 & 580 & 351 & 53.15 & 13.78 & 12.07 & 9.38 & 38.58 & 72.73 & 33.28 \\
\hline BH-661(100 \%RR) & 436 & 188 & 304 & 285 & 274 & 693 & 363 & 23.43 & 14.56 & 12.74 & -0.12 & 22.40 & 45.38 & 19.73 \\
\hline BH- 660(50\%RR) & 366 & 129 & 248 & 128 & 214 & 440 & 254 & 1.38 & 12.67 & 8.15 & -9.25 & 27.77 & 65.44 & 17.69 \\
\hline BH-660(100 \%RR) & 242 & 130 & 320 & 207 & 201 & 398 & 250 & -11.23 & 5.28 & 9.85 & -4.35 & 15.71 & 45.66 & 10.15 \\
\hline BH-140(50 \% RR) & 317 & 105 & 167 & 149 & 195 & 264 & 200 & 18.04 & -6.84 & 12.73 & -29.8 & 15.75 & 45.40 & 9.21 \\
\hline BH-140(100 \%RR) & 285 & 134 & 270 & 380 & 230 & 360 & 277 & -3.26 & 1.30 & 15.81 & 0.89 & 11.41 & 25.79 & 8.66 \\
\hline BH-543 & 175 & 109 & 174 & 236 & 143 & 230 & 178 & & & & & & & \\
\hline Mean & 328 & 150 & 291 & 233 & 201 & 392 & & 11.40 & 6.29 & 12.62 & -9.45 & 16.55 & 47.53 & \\
\hline
\end{tabular}

F-1-F6= Farmers name (Takele Uluma, Adisu Fufa, Adisu Likessa, Mulatu Shukar, Tesfaye Tsagaye and Gutu Tolera), 50 \% and $100 \%$ RR= half and full doses (55 and $110 \mathrm{~kg} \mathrm{~N} \mathrm{ha}^{-1}$ ) recommended for maize. 
Agronomic efficiency of maize varieties was varied across farms and among varieties (Table 6). Higher mean agronomic efficiency of 6,11,13, 17 and $48 \mathrm{~kg}$ grain kg N applied ${ }^{-1}$ in increasing order were obtained farm 2, farm 1, farm 3, farm 5 and farm 6. Farm 5 and farm 6 were gave better productivity of maize varieties as compared to other farms. Higher mean agronomic efficiency of maize varieties was produced form all maize varieties with half recommended nitrogen fertilizer application as compared to full recommended nitrogen application. This indicates all maize varieties had higher agronomic efficiency at lower nitrogen application. Agronomic efficiency of maize varieties was ranged from 9 to 33 and 9 to $20 \mathrm{~kg}_{\text {grain }} \mathrm{kg} \mathrm{N}_{\text {applied }}{ }^{-1}$ with half and full recommended nitrogen fertilizer application. Better agronomic efficiency was obtained with all varieties under lower rates of nitrogen fertilizer. Agronomic efficiency is defined as extra crop yield produced per unit of fertilizer nutrient applied. Maximizing Agronomic efficiency also minimizes the risk that fertilizer nutrients move beyond the rooting zone into the environment and pollute water sources [52]. Vanlauwe et al. [53] suggested the use of improved germplasm is essential to ensure that the supply of nutrients is matched with an equivalent demand for those nutrients. All inputs need to be managed following sound agronomic principles [54]. The highest and lowest mean agronomic efficiency was received from BH-661 and BH-140. This indicates maize varieties with higher agronomic efficiency were produced higher mean grain yield.

\subsection{Nitrogen up take efficiency, Nitrogen physiological efficiency and fertilizer $\mathbf{N}$ use efficiency of maize}

The summarized results of nitrogen uptake efficiency, nitrogen use efficiency and fertilizer $\mathrm{N}$ use efficiency are indicated in Table 7 and 8. Across farms mean nitrogen uptake efficiency of $0.51,0.78,1.78,2.25,2.32$ and $2.65 \mathrm{~kg} \mathrm{~N}$ uptake $\mathrm{kg} \mathrm{N}$ applied ${ }^{-1}$ were obtained from maize varieties planted on farm 2, farm 5, farm3, farm 1, farm 6 and farm 4, respectively (Table 7). Farm1, farm6 and farm4 had better nitrogen uptake efficiency of maize varieties among other farms. Significantly better maize production was obtained from the above three farms. The three farms had better soil fertility status and productive potentials of maize varieties. BH-140 and BH-660 maize varieties were had higher nitrogen uptake efficiency at half recommended nitrogen application whereas BH-540, BH-543 and BH-661 were had at recommended nitrogen fertilizer application. 
Table 7. Effects of varieties and nitrogen rate on nitrogen up take efficiency and nitrogen use efficiency of maize on farmer's field around Bako-Tibe, western Ethiopia

\begin{tabular}{|c|c|c|c|c|c|c|c|c|c|c|c|c|c|c|}
\hline \multirow{3}{*}{$\begin{array}{c}\text { Maize varieties with } \\
\text { N rates }\end{array}$} & \multicolumn{7}{|c|}{ nitrogen up take efficiency $\left(\mathrm{kg} \mathrm{N}\right.$ uptake $\mathrm{kg} N$ applied $\left.{ }^{-1}\right)$} & \multicolumn{7}{|c|}{ Plant nitrogen use efficiency (kg grain kg N uptake ${ }^{-1}$ ) } \\
\hline & \multicolumn{3}{|c|}{2013} & \multicolumn{3}{|c|}{2014} & \multirow[t]{2}{*}{ Mean } & \multicolumn{3}{|c|}{2013} & \multicolumn{3}{|c|}{2014} & \multirow[t]{2}{*}{ Mean } \\
\hline & Farm 1 & Farm 2 & Farm 3 & Farm4 & Farm5 & Farm6 & & Farm 1 & Farm 2 & Farm 3 & Farm 4 & Farm 5 & Farm 6 & \\
\hline BH-540(50\%RR) & 2.71 & -0.58 & 2.02 & 2.98 & -0.55 & 1.38 & 7.96 & -1.09 & -0.75 & 12.59 & 27.10 & -18.47 & 43.74 & 10.52 \\
\hline BH-540(100\%RR) & 0.22 & 0.63 & 0.83 & 1.97 & 0.82 & 0.58 & 5.05 & 33.29 & 5.99 & 8.65 & -311.25 & 19.80 & 64.50 & -29.84 \\
\hline BH-543(50\%RR) & 1.65 & 0.80 & 3.96 & 3.16 & 0.85 & 1.82 & 12.25 & 7.91 & 13.30 & 2.21 & 24.38 & 14.74 & 28.27 & 15.14 \\
\hline BH-543(100 \%RR) & 3.85 & 1.25 & 1.41 & 2.43 & 0.58 & 1.67 & 11.20 & 3.92 & 5.86 & 9.60 & -17.26 & 1.08 & 15.24 & 3.07 \\
\hline BH-661(100 \%RR) & 2.37 & 0.72 & 1.18 & 2.38 & 1.19 & 4.21 & 12.05 & 9.87 & 20.28 & 10.78 & -0.27 & 18.81 & 10.78 & 11.71 \\
\hline BH- 660(50 \%RR) & 3.47 & 0.36 & 1.35 & 1.91 & 1.29 & 3.82 & 12.20 & 0.40 & 34.85 & 6.05 & 4.71 & 23.83 & 17.14 & 14.50 \\
\hline BH-660(100 \%RR) & 0.61 & 0.19 & 1.33 & 1.67 & 0.53 & 1.53 & 5.85 & -18.43 & 27.67 & 7.42 & 16.52 & 26.76 & 29.90 & 14.97 \\
\hline BH-140(50\%RR) & 2.58 & -0.07 & -0.13 & 2.29 & 0.95 & 0.62 & 6.24 & 6.99 & 94.00 & -100 & 18.84 & 16.65 & 73.44 & 18.32 \\
\hline BH-140(100 \%RR) & 1.00 & 0.23 & 0.87 & 3.25 & 0.79 & 1.18 & 7.32 & -3.26 & 5.72 & 18.11 & 0.68 & 14.43 & 21.82 & 9.58 \\
\hline
\end{tabular}

Farm 1- 6= farmers name (Takele Uluma, Adisu Fufa, Adisu Likessa, Mulatu Shukar, Tesfaye Tsagaye and Gutu Tolera), $50 \%$ and $100 \%$ RR= half and full doses (55 and $110 \mathrm{~kg} \mathrm{~N} \mathrm{ha}^{-1}$ ) recommended for maize. 
The nitrogen uptake efficiency of maize varieties was ranged from 6.24-22.76 and 5.05$12.05 \mathrm{~kg} \mathrm{~N}$ uptake $\mathrm{kg} \mathrm{N}$ applied $^{-1}$ with half and full recommended nitrogen fertilizer application. The nitrogen utilization efficiency decreased as the rate of nitrogen fertilizer increased and varieties differed significantly in $\mathrm{N}$ utilization efficiency [55]. Similarly, Correia Granato et al. [56] found nitrogen absorption (uptake) efficiency was showed greater genetic variability under low $\mathrm{N}$ availability. The highest mean nitrogen uptake efficiency was obtained from BH-661 followed BH-660 and BH-543 among other varieties of maize. Therefore BH-661> BH-660> BH-543 were the most promising varieties with nitrogen uptake efficiency and sustainable production of maize in the region.

The nitrogen physiological efficiency of maize varieties was varied across farms, nitrogen rates and among maize varieties used (Table 7). Mean nitrogen physiological efficiency of $5.27,21.55,-2.22,-21.99,14.67$ and $31.63 \mathrm{~kg}$ grain $\mathrm{kg} \mathrm{N}$ uptake $^{-1}$ were obtained from varieties planted on farm1-6 respectively. Farm 1, farm 2, farm 5 and farm 6 were had better nitrogen physiological efficiency as compared to other farms. This indicates producing maize varieties on these four farms had a good potential for sustainable maize production in the region which implies better fertility status of the above four farms. Soil quality heterogeneity has been shown to be a factor in NUE on smallholder production fields, with much lower NUE in 'outfields' which are extensively management and sometimes associated with low soil organic matter [57]. The mean nitrogen physiological efficiency of maize varieties ranged from 10.52 to 18.32 for half recommended nitrogen application and 29.84 to $14.97 \mathrm{~kg}$ grain $\mathrm{kg} \mathrm{N}$ uptake $^{-1}$ for full recommended nitrogen fertilizer (Table 7). Except BH-140, all other maize varieties were showed better nitrogen physiological efficiency at half recommended nitrogen fertilizer application. Higher mean nitrogen physiological efficiency of maize varieties was obtained from half recommended nitrogen application as compared to full recommended nitrogen rate. Enhanced efficiency fertilizer (EEF) can improve the crop $\mathrm{N}$ use efficiency (NUE) as well as minimize negative environmental losses compared to conventional fertilizers [58,59]. Hart et al. [60] reported nitrogen use effectiveness at increasing the NUE of corn has been variable. Presterl et al. [61] observed that nitrogen absorption (uptake) efficiency and nitrogen utilization efficiency were contributed to the genetic variation in NUE. Zhu [62]; and Raun and Johnson [17] reported large amounts of $\mathrm{N}$ fertilizers are required to attain maximum yield and for which NUE is estimated to be far less than $50 \%$. Estimates of NUE on maize plots derived from nationally 
representative and site-specific household survey data in Malawi are typically in the range of 7 to 14 [63-66]. Vanlauwe et al. [67]; and Whitbread et al. [68] reported nitrogen use efficiency on maize plots following researcher management protocols can be in the range of 14 to $50 \mathrm{~kg}$ maize per $\mathrm{kg}$ nitrogen $(\mathrm{N})$ and even higher in some cases. The average nitrogen use efficiency (NUE) was 89 and $67 \%$ for the plots receiving 80 and $160 \mathrm{lb}$ N/A and ear yield and NUE could be maximized by applying only $80 \mathrm{lb}$ N/A [50] (Heinrich et al., 2013). Nitrogen use efficiency is highest for the first unit of added $\mathrm{N}$ and it decreases with the increase in rate of $\mathrm{N}$ fertilization [69]. Similarly, Agostini et al. [70]; Burns [71] stated the optimization of fertilization and the improvement of NUE of crops to achieve high yields with reduced $\mathrm{N}$ fertilization rates and limited environmental side effects related to $\mathrm{N}$ leaching. Bertin and Gallais [72] reported that the genetic variability in NUE under conditions of low $\mathrm{N}$ is primarily due to differences in nitrogen utilization efficiency. In contrast, Dovale et al. [73] and LeGouis et al. [42] concluded that the most important component for NUE under low $\mathrm{N}$ availability is nitrogen absorption (uptake) efficiency. Enhanced NUE may result from increased efficiency of recovery of soil available N (uptake efficiency) and higher efficiency of utilization of the $\mathrm{N}$ taken up for grain formation (utilization efficiency) [14]. The highest nitrogen physiological efficiency was obtained from BH-661 followed by BH-660 and BH-543. Anbessa and Juskiw [43] suggested increase in NUE may allow growers ultimately to maximize yield under moderate $\mathrm{N}$ conditions rather than the need for high $\mathrm{N}$ conditions. The optimization of NUE rests on management practices that can counter $\mathrm{N}$ losses from the soil plant system [17]. Therefore, these three maize varieties had better potential for sustainable maize production and/or uses to develop nitrogen efficient varieties through breeding strategies.

The fertilizer $\mathrm{N}$ (recovery) use efficiency was varied across farms and nitrogen rates applied. Fertilizer $\mathrm{N}$ use efficiency was ranged from 52 to 232 among farms except farm 4 (Table 8). Farm 4 had negative fertilizer $\mathrm{N}$ use efficiency indicating very poor soil fertility status due termite problem during operation and needs higher investment to replenish the soil and use it for maize production. Application of half recommended nitrogen fertilizer gave higher range 39 to 312 fertilizer $\mathrm{N}$ use efficiency as compared to maize varieties planted with full recommended nitrogen fertilizer (52 to 169). BH-661, BH-543, BH-660 and BH-540 in descending order gave better fertilizer N recovery use efficiency. Significantly better fertilizer $\mathrm{N}$ use efficiency was obtained with half recommended nitrogen fertilizer application. 
Table 8. Effects of varieties and nitrogen rate on Fertilizer $\mathrm{N}$ use efficiency of maize on farmer's field around Bako Tibe, western Ethiopia.

\begin{tabular}{lccccccc}
\hline \multirow{2}{*}{ Maize varieties + N Kg ha-1 } & \multicolumn{7}{c}{ Fertilizer N (recovery) use efficiency (\%) } \\
\cline { 2 - 8 } & Farm1 & Farm2 & Farm3 & Farm4 & Farm5 & Farm6 & Mean \\
\hline BH-540(50 \%RR) & 271 & -58 & 201 & -89 & -55 & 139 & 68 \\
BH-540(100 \%RR) & 22 & 63 & 83 & 3 & 82 & 58 & 52 \\
BH-543(50\%RR) & 165 & 81 & 397 & -70 & 86 & 182 & 140 \\
BH-543(100 \%RR) & 386 & 126 & 141 & 49 & 58 & 167 & 155 \\
BH-661(50\%RR) & 406 & 160 & 499 & 57 & 132 & 637 & 315 \\
BH-661(100\%RR) & 238 & 72 & 118 & 44 & 119 & 421 & 169 \\
BH- 660(50\%RR) & 348 & 36 & 134 & -196 & 130 & 381 & 139 \\
BH-660(100\%RR) & 61 & 19 & 132 & -27 & 53 & 153 & 65 \\
BH-140(50\%RR) & 258 & -7 & -14 & -158 & 95 & 62 & 39 \\
BH-140(100\%RR) & 100 & 23 & 87 & 131 & 79 & 118 & 90 \\
Mean & 226 & 52 & 178 & -26 & 78 & 232 & \\
\hline
\end{tabular}

F-1-F6= Farmers name (Takele Uluma, Adisu Fufa, Adisu Likessa, Mulatu Shukar, Tesfaye Tsagaye and Gutu Tolera), $50 \%$ and $100 \% \mathrm{RR}=$ half and full doses (55 and $110 \mathrm{~kg} \mathrm{~N} \mathrm{ha}^{-1}$ ) recommended for maize.

The apparent $\mathrm{N}$ fertilizer recovery decreased as the rate of nitrogen fertilizer increased [55]. Anbessa and Juskiw [43] stated increased $N$ recovery and utilization efficiency may allow growers to maximize yield under a moderate rate of $\mathrm{N}$ fertilization instead of the traditional high rate of $\mathrm{N}$ fertilization. Soil $\mathrm{N}$ recovery and utilization efficiency may be increased through improved $\mathrm{N}$ management strategies that counter $\mathrm{N}$ losses from the soilplant system plus a superior capacity of the crop cultivar to take up and use available $\mathrm{N}$ [14]. Anbessa and Juskiw [49] found combination of improved $\mathrm{N}$ management practices and more efficient cultivars should bring about a significant increase in NUE under low to moderate $\mathrm{N}$ application rates. The percentage $\mathrm{N}$ recovery varied among the genotypes tested, demonstrating that maize varieties may differ in total $\mathrm{N}$ loss [74]. Nitrogen is the key driver for cereal crop performance across most environments, both in terms of yield and stability of yield [67]. Snapp et al. [75] reported raising the efficiency of nitrogen use by maize is therefore crucial for the sustainability and economic feasibility of land intensification in the region. Hoisington et al. [76] stated the effective use of plant genetic resources will be required to meet the challenge posed by the world's expanding demand for food, the fight against hunger, and the protection of the environment. The mechanisms controlling plant $\mathrm{N}$ 
economy is essential for improving NUE and for reducing excessive input of fertilizers, while maintaining an acceptable yield and sufficient profit margin for the farmers [77].

Considering both economically and environmental challenge by reducing both the cost and application of $\mathrm{N}$ fertilizers were possible through improving NUE. Moreover, improvement in yield for most crops over the last 50 years has been estimated to be $40 \%$, due to improvements in cultural practices and $60 \%$ due to genetic gains, thus indicating that testing for improved NUE is still possible [78] (Edgerton, 2009). The ratio of plant $\mathrm{N}$ content to the $\mathrm{N}$ supplied does not exceed $50 \%$ whatever the level of $\mathrm{N}$ fertilization [79], which suggests that improvement of NUE in this species is also a possibility [80]. Identification maize varieties with better NUE were agronomically and economically feasible and environmental safe for sustainable maize production and desirable for further breeding use. Strategies to improve NUE are to use genetic modification or to breed for new varieties that take up more organic or inorganic $\mathrm{N}$ from the soil $\mathrm{N}$ and utilize the absorbed $\mathrm{N}$ more efficiently $[8,81]$. Therefore, application of half recommended nitrogen fertilizer had better potentials for sustainable maize production in better soil fertility status.

\section{Conclusion}

Soil fertility problem was alleviated using improved crop management practices. Maize varieties were produced significantly different biological and grain yield. Application of nitrogen fertilizer gave significantly higher mean grain yield maize. Higher nitrogen uptake of all maize varieties was obtained at full recommended nitrogen fertilizer application as compared to half recommended nitrogen fertilizer application indicating positive relation of nitrogen fertilizer application with nitrogen up take. Agronomic efficiency of maize varieties was ranged from 9.21 to 32.28 and 8.66 to 19.73 with half and full recommended nitrogen fertilizer application.BH-661 followed by BH-660 and BH-543 had higher nitrogen uptake efficiency and plant nitrogen use efficiency and recommended for wide production in the region. Significantly better fertilizer $\mathrm{N}$ use efficiency was obtained with half recommended nitrogen fertilizer application. Significantly better fertilizer N use efficiency was obtained with half recommended nitrogen fertilizer application indicating better potentials half recommended nitrogen fertilizer for sustainable maize production in better soil fertility status. Application of nitrogen fertilizer was increased shoot and grain $\mathrm{N}$ accumulation of maize varieties. Higher nitrogen harvest index of maize varieties was obtained with half 
recommended nitrogen fertilizer as compared maize varieties planted with full recommended nitrogen fertilizer application. Planting of BH-661, BH-660, BH-540 and BH-543 maize varieties with half recommended nitrogen fertilizer rate was agronomically gave higher grain yield and economical feasible for sustainable maize production. Identifying maize varieties with better nitrogen use efficiency was very crucial to reduce cost production for stallholder farmers and environmental pollination. In conclusion planting of maize varieties with optimum nitrogen application was far most important for sustainable maize production in the agroecology. In conclusion, the results empathy of NUE maize varieties with good agronomic practices is essential components of sustainable maize production in the area.

Acknowledgements: First, I would like to thank the almighty God who lives us and lead us to see seed of my work. The authors thank Regional University Fund for Capacity Building in agriculture, I am very grateful to Ambo Agricultural Research center management for providing me all necessary equipment's and logistics during the research work. All the technical and field assistants of Land and Water Resources Research Process are also acknowledged for unreserved effort during executing the experiment. Ambo Plant Protection Research center, Holleta and Debre Zeit Agricultural Research Center, Soil and Plant Analysis Laboratory are acknowledged for their provision of laboratory service for soil. I want to thank Bako Tibe and Ilu Gelan farmers for providing me land for field research work and their assistance in field managements

Author Contributions: Tolera Abera conceived of, designed and performed the experiments. Tolera Abera, Dagne Wegary and Tolessa Debele analyzed the data and wrote the paper.

Conflicts of Interest: The authors declare no conflict of interest.

\section{References}

1. Eckert, D. Efficient Fertilizer Use Manual-Nitrogen. www.back-tobasics.net/efu/pdfs/Nitrogen.pdf, 1999.

2. Gallais, A.; Hirel, B. An approach to the genetics of nitrogen use efficiency in maize. J. of Exper. Bot. 2004, 55, 295-306. 
3. Frink, C.R.; Waggoner, P.E.; Ausubel, J.H. Nitrogen Fertilizer: Retrospect and Prospect. Proceeding of National Academics Science. USA. 1999, 4,1175-1180.

4. Tayefe, M.; Gerayzade, A.; Amiri, E.; Zade, A.N. (2011). Effect of nitrogen fertilizer on nitrogen uptake, nitrogen use efficiency of rice. In: International Proceeding of Chemical, Biological and Environmental Engineering. (Edited by Baby S, and Dan Y.), 24:470-473.

5. Yuan, Z.Y.; Li, L.H.; Huang, J.H.; Han, X.G.; Wan, S.Q. Effect of nitrogen supply on the nitrogen use efficiency of an annual herb, Helianthus annuus L. J. Integrated Plant Biol.2005,47(5),539-548.

6. Zhang, N.; Gibon, Y.; Gur, A.; Chen, C.; Lepak, N.; Ho“hne, M.; Zhang, Z.; Kroon, D.; Tschoep, H.; Stitt, M.; Buckler, E. Fine Quantitative Trait Loci Mapping of Carbon and Nitrogen Metabolism Enzyme Activities and Seedling Biomass in the Maize IBM Mapping Population. Plant Physi. 2010,154, 1753-1765.

7. Glass A.D.M. Nitrogen use efficiency of crop plants: physiological constraints upon nitrogen absorption. Critical Revi. in Plant Sci, 2003, 22, 453-470.

8. Good, A.G.; Shrawat, A.K.; Muench, D.G. Can less yield more? Is reducing nutrient input into the environment compatible with maintaining crop production? Trends Plant Sci. 2004, 9, 597-605.

9. Dobermann, A.R. Nitrogen use efficiency: state of the art. Agronomy - Faculty Publications. Agronomy and Horticulture Department of Nebraska - Lincoln. 2005. www.digitalcommons.unl.edu/agronomyfacpub/316.

10. .Machado, A.T.; Sodek, L.; Fernandes, M.S. N-partitioning, nitrate reductase and glutamine synthetase activities in two contrasting varieties of maize. Pesq. Agropec. Bras. 2001,2, 249-256.

11. Moose, S.; Below, F.; Buckler, E.S. Gene discovery for maize responses to nitrogen. Research project. University of Illinois at Urbana Champaign. USA. nitrogenes.cropsci.illinois.edu/NSFPG\% 20Maize\%20NUE\%20proposal.pdf. 2005

12. Food and Agricultural Organization (FAO). Current world fertilizer trends and outlook to 2015. Food and Agriculture Organization of the United Nations. Rome. ftp://ftp.fao.org/ag/agp/docs/cwfto15.pdf. 2011.

13. Rehman, A.; Saleem, M. F.; Safdar, M. E.; Hussain, S.; Akhtar, N. Grain quality, nutrient use efficiency, and bioeconomics of maize under different sowing methods and NPK levels. Chilean J. of Agric. Res. 2011, 71, 586-593. 
14. Moll, R. H.; Kamprath, E. J.; Jackson, W. Analysis and interpretation of factors which contribute to efficiency of nitrogen utilization. Agron. J.1982,74, 562-564.

15. Coque, M.; Gallais, A. Genetic variations among European maize varieties for nitrogen use efficiency under low and high nitrogen fertilization. Maydica 2007,52, $383-397$.

16. Ma, B.L.; Dwyer, L.M. Nitrogen uptake and use of two contrasting maize hybrid differing in leaf senescence. Plant and Soils. 1998,199, 283-291.

17. Raun, W. R.; Johnson, G. V. Review and interpretation improving nitrogen use efficiency for cereal production. Agron. J. 1999, 91, 357-363.

18. MBARC (Meteorological Station of Bako Agricultural Research Center). Meteorological data of Bako area for 1960-2014. Bako, Oromia, Etiopia. 2014.

19. NMSA (National Meteorological Service Agency). Meteorological data of Ilu-Gelan area for 2009-2014. NMSA, Addis Ababa, Etiopia. 2014

20. FAO (Food and Agricultural Organization). FAO World Reference Base for Soil Resources. World Soil Resources Report 103. FAO, Rome. 2007, 128 pp.

21. Dewis, J.; Freitas, F. Physical and chemical methods of soil and water analysis. FAO Soil Bulletin No. 10. FAO, Rome. 1984, 275 pp.

22. Walkley, A.; Black, C.A. An examination of Degtjareff method for determining soil organic matter and the proposed modification of the chromic acid titration method. Soil Sci. 1934, 37, 29-38.

23. Jackson, M.L. Soil chemical analysis. Prentice Hall, Inc., Engle Wood Cliffs. New Jersey. 1985, pp. 183-204.

24. Bray, R. H.; Kurtz, L.T. "Determination of total, organic and available forms of phosphorus in soils, ” Soil Sci.1945, 59, 39- 45.

25. Keeney, D.R.; Nelson, D.W. Nitrogen in organic forms. In: Methods of Soil Analysis. (Edited by Page, A.L., Miller, R.H. and Keeney. D.R.), Agronomy. Part II, No. 9, American Society of Agronomy. Madison, Wisconsin, USA, 1982, 643-698.

26. Birru A. Agricultural Field Experiment Management Manual Part III. IAR (Institute of Agricultural Research). Addis Ababa, Ethiopia, 1979, 35-42.

27. Nelson, L.A.; Voss, R.D.; Pesek, J. Agronomic and statistical evaluation of fertilizer response $1985,89 \mathrm{pp}$.

28. Murphy, J.; Riley, J.P. A modified single solution method for the determination of phosphate in natural waters. Analyt. Chem. Acta. 1962, 27, 31-36. 
29. Cleemput O. Van.; Zapata F.; Vanlauwe B. Use of tracer technology in mineral fertilizer management. In: Guidelines on Nitrogen Management in Agricultural Systems. International Atomic Energy Agency, Austria, Vienna, 2008, 19-126.

30. Haegele, J. W. Genetic and Agronomic Approaches to Improving Nitrogen Use and Maize Productivity. PhD dissertation, University of Illinois, Urbana-Champaign, 2012, 187 p.

31. Azizian, A.; Sepaskhah, A. R. Maize response to different water, salinity and nitrogen levels: Agronomic behavior. Inter. J. of Plant Produ. 2014, 8, 107-130.

32. SAS. 2004. SAS/STAT Software Syntax, Version 9.0. SAS Institute, Cary, NC. USA

33. Steel, R.G.D.; Torrie, J.H. Principles and procedures of statistics: a biometrical approach. $2^{\text {nd }}$ Edition. McGraw-Hill. New York. 1980, 631pp.

34. London, J.R. (Ed.). Booker tropical soil manual: A hand book for soil survey and agricultural land evaluation in the tropics and subtropics. Longman.1991, 254 PP

35. FAO (Food and Agricultural Organization). Guideline for Soil Description. Rome, Italy 1990, 193 pp.

36. Bruce, R. C.; Rayment, G. E. Analytical methods and interpretations used by the Agricultural Chemistry Branch for Soil and Land Use Surveys. Queensland Department of Primary Industries. Bulletin QB8 (2004), Indooroopilly, Queensland. 1982

37. Horneck, D.A.; Sullivan, D.M.; Owen, J.S.; Hart, J.M. Soil test interpretation guide. EM 1478. Corvallis, OR: Oregon State University Extension Service. 2011, 12p.

38. Bashour, I. Fertility and fertilizer requirements. In: Rural integrated development of the mountains of northern Lebanon. FAO/Ministry of Agriculture, Lebanon. 2002, 197pp.

39. FAO (Food and Agricultural Organization). Near East fertilizer-use manual. FAO/14152/F. Rome, Italy. 2006, 197 pp.

40. Marx, E.S.; Hart, J.; Stevens, R.G. Soil test interpretation guide. EC 1478. Oregon State University Extension service. 1999, 8pp.

41. Raun, W. R.; Ortiz-Monasterio, I.; Solie, J. B. Temporally and spatially dependent nitrogen management for diverse environments. Section II Making of a Wheat Crop. 2009, 203-214.

42. Le Gouis, J.; Be'ghin, D.; Heumez, E.; Pluchard, P. Genetic differences for nitrogen uptake and nitrogen utilization efficiencies in winter wheat. Europ. J. of Agron. 2000, $12,163-173$. 
43. Anbessa, Y.; Juskiw, P. Nitrogen Fertilizer Rate and Cultivar Interaction Effects on Nitrogen Recovery, Utilization Efficiency, and Agronomic Performance of Spring Barley. doi:10.5402/2012/531647. Intern. Scholarly Res. Network ISRN Agron.2012a, $1-9$.

44. Tollenaar, M.; Ahmadzadeh, A.; Lee, E. A. Physiological basis of heterosis for grain yield in maize. Crop Sci. 2004, 44, 2086-2094.

45. Lemaire, G.; van Oosterom, E.; Sheehy, J.; Jeuffroy, M. H.; Massignam, A.; Rossato, L. Is crop $\mathrm{N}$ demand more closely related to dry matter accumulation or leaf area expansion during vegetative growth. Field Crop Res. 2007, 100, 91-106.

46. Gava, G.J.C.; Oliveria, M.W.; Silva, M.A.; Jeronimo, E.M.; Cruz, J.C.S.; Trivelin, P.C.O. Phytomass production and nitrogen accumulation in maize cultivated with different doses of ${ }^{15} \mathrm{~N}$-urea. Agric. Sci. 2010, 3(4), 851-862.

47. Araujo, E. de O.; Martins, M.R.; Mercante, F.B.; Tadeu, V.; Itorino, A.C.; Urguiaga. S.S. Herbasprillum seropedicae inoculation and nitrogen fertilization on nitrogen use efficiency of different corn genotypes. Afr. J. of Agric. Res. 2014, 9(40), 3025-3031.

48. Heath, R. The potential for increased nitrogen use efficiency with improved agronomy and developing technology. Australian Nuffield Farming Scholars Association. "Pinecliff" CURLEWIS NSW 2381. Nuffield Scholar sponsored by GRDC. Grain Research and Development Corporation. 2002, 25pp.

49. Anbessa, Y., Juskiw, P. Review: Strategies to increase nitrogen use efficiency of spring barley. Cana. J. Plant Sci. 2012b, .92, 617-625.

50. Heinrich, A.; Sullivan, D.; Peachey, Ed. Improving fertilizer P and N use efficiency in sweet corn. Research report to the Oregon Processed Vegetable Commission. Crop and Soil Sci. OSU. 2013, 36pp.

51. Anbessa, Y.; Juskiw, P.; Good, A.; Nyachiro, J.; Helm, J. Genetic variability in nitrogen use efficiency of spring barley. Crop Sci. 2009, 49, 1259-1269.

52. Vanlauwe, B.; Giller, K. E. Popular myths around soil fertility management in subSaharan Africa. Agric. Ecosys. Environ. 2006, 116, 34-46.

53. Vanlauwe, B.; Descheemaeker, K.; Giller, K. E.; Huising, J.; Merckx, R.; Nziguheba, G.; Wendt, J.; Zingore, S. Integrated soil fertility management in sub-Saharan Africa: unraveling local adaptation. SOIL Discuss. 2014, 1, 1239-1286.

54. Vanlauwe, B.; Bationo, A.; Chianu, J.; Giller, K. E.; Merckx, R.; Mokwunye, U.; Ohiokpehai, O.; Pypers, P.; Tabo, R.; Shepherd, K.; Smaling, E. M. A.; Woomer, P. 
L. Integrated soil fertility management: Operational definition and consequences for implementation and dissemination. Outlook Agric. 2010, 39, 17-24.

55. Moser, S. B. Effects of pre-anthesis drought stress and nitrogen on yield, nitrogen use efficiency, and grain minerals of tropical maize varieties. Dissertation for Award of $\mathrm{PhD}$ degree in Natural Sciences at Swiss federal Institute of Technology Zurich, Zurich, Switzerland. 2004, 106pp.

56. Correia Granato, Í. S.; Bermudez, F. P.; dos Reis, G. G.; Dovale, J. C.; Miranda, G. V.; Fritsche-Neto, R. (2012). Index selection of tropical maize genotypes for nitrogen use efficiency . Crop Prod. and Manag. 2012, 73 (2), 153-159.

57. Vanlauwe, B.; Kihara, J.; Chivenge, P.; Pypers, P.; Coe, R.; Six. J. Agronomic use efficiency of $\mathrm{N}$ fertilizer in maize-based systems in sub-Saharan Africa within the context of integrated soil fertility management. Plant and Soil. 2011, 339, 35-50.

58. Guertal, E.A. Slow-release Nitrogen Fertilizers in Vegetable Production: A Review. Hort. Techn. 2009, 19: 16-19.

59. Shoji, J., Maehara, T.; Aoyama, M.; Fujimoto, H.; Iwamoto,A.; Tanaka, M. Daily ration of Japanese Spanish mackerel Scomberomorus niphonius larvae. Fisher Sci. 2001, 67, 238-245.

60. Hart, M.; Belton, P.; Gries, G. The effect of fibril erection on hearing in male Aedes togoi: an open and shut case. Canad. Acoustics, 2010.38 (3): 36-37.

61. Presterl, T.; Groh, S.; Landbeck, M.; Seitz, G.; Schmidt, W.; Geiger, H.H. Nitrogen uptake and utilization efficiency of European maize hybrids developed under conditions of low and high nitrogen input. Plant Breeding. 2002, 121, 480-486.

62. Zhu, Z. Loss of fertilizer $\mathrm{N}$ from the plant-soil system and the strategies and techniques for its reduction in China. Soil Environ. Sci. 2000, 9, 1-6.

63. Chibwana, C.; Fisher, M.; Shively, G. Cropland allocation effects of agricultural input subsidies in Malawi. World Dev. 2012, 40 (1), 124-133.

64. Ricker-Gilbert, J.; Jayne, T.S. What are the enduring effects of fertilizer subsidy programs on recipient farm house-holds? Evidence from Malawi. Staff PaperDepartment of Agricultural, Food, and Resource Economics, Michigan State University. East Lansing, MI: MSU, 2011.

65. Snapp, S.S.; Chikowo, R.; Ivanyna, M. Ecological intensification and farmerresearcher partnerships. Invited talk at the Symposium on "Transforming Productivity and Incomes of Poor Farm Households in the Developing World' at the American Association for the Advancement of Science, 14-18 February 2013, Boston, MA. 
66. Wiyo, K.; Feyen, J. Assessment of the effect of tie-ridging on smallholder maize yields in Malawi. Agric. Water Manag. 1999, 41, 21-39.

67. Vanlauwe, B.; Wendt, J.; Giller, K.E.; Corbeels, M.; Gerard, B.; Nolte C. A fourth principle is required to define Conservation Agriculture in sub-Saharan Africa: the appropriate use of fertilizer to enhance crop productivity. Field Crop Res. 2013, 155, 10-13.

68. Whitbread, A.; Sennhenn, A.; Grotelüschen, K. Nitrogen-use-efficiency in maizebased farming systems in Malawi: A simulation study and meta-analysis of literature. Göttingen, Germany: Faculty of Agricultural Sciences, University of Gottingen.2012.

69. Tilman, D.; Cassman, K. G.; Matson, P. A.; Naylor, R.; Polasky, S. Agricultural sustainability and intensive production practices. Nature. 2002,418, 671-677.

70. Agostini, F.; Tei. F.; Silgram, M.; Farneselli, M.; Benincasa, P.; Aller, M.F. Decreasing $\mathrm{N}$ leaching in vegetable crops through improvements in $\mathrm{N}$ fertilizer management. In: Genetic engineering, biofertilisation, soil quality and organic farming. (Edited by Lichtfouse, E.), Springer, Dordrecht, The Netherlands. Susta. Agric. Revis. 2010, 4, 147-200.

71. Burns, I.G. Assessing $\mathrm{N}$ fertilizer requirements and the reliability of different recommendation systems. Acta Horticulture 2006, 700, 35-48.

72. Bertin, P.; Gallais, A. Genetic variation for nitrogen use efficiency in a set of recombinant maize inbred lines I. Agrophysiological results. Maydica 2000, 45, 5366.

73. Dovale, J.C.; Fritsche-Neto, R.; Bermudez, F.; Miranda, G.V. Efeitos gênicos de caracteres associados à eficiência no uso de nitrogênio em milho. Pesquisa Agropecuária Brasileira 2012, 47, 385-392.

74. Chevalier, P., Schrader, L.E. Genotypic differences in nitrate absorption and partitioning of $\mathrm{N}$ among plant parts in maize. Crop Sci. 1977, 17: 897-901.

75. Snapp, S.; Jayne, T.S.; Mhango, W.; Benson, T.; Ricker-Gilbert, J. Maize Yield Response to Nitrogen in Malawi's Smallholder Production Systems. Working Paper 9. Malawi Strategy Support Program. International Food Police Research Institute (IFPRI). 2014, 13pp.

76. Hoisington, D.; Khairallah, M.; Reeves, T.; Ribault, J.M.; Skovmand, B.; Taba, S.; Warburton, M. Plant genetic resources: what can they contribute toward increased crop productivity? Proceedings of the National Academy of Sciences, USA 1999, 96, $5937-5943$. 
77. Hirel, B.; Tétu, T.; Lea, P. J.; Dubois, F. Improving nitrogen use efficiency in crops for sustainable agriculture. Susta. 2011, 3, 1452-1485.

78. Edgerton, M.D. Increasing crop productivity to meet global needs for feed, food and fuel. Plant Physi.2009, 149, 7-13.

79. Malagoli, P.; Laine, P.; Rossato, L.; Ourry, A. Dynamics of nitrogen uptake and mobilization in field-grown winter oilseed rape (Brassica napus) from stem extension to harvest. Ann of Bot. 2005; 95; 853-861.

80. Hirel, B.; Le Gouis, J.; Ney, B.; Gallais, A. The challenge of improving nitrogen use efficiency in crop plants: towards a more central role for genetic variability and quantitative genetics within integrated approaches. Nitrogen Nutrition Special Issue. J. Experi. Bot. 2007, 58, 2369-2387. 